\title{
Moments of Islamic and Orientalist Discourse in the Anticlerical Perspective of Voltaire
}

\author{
Edvin Cami \\ University "Aleksandër Moisiu", Durrës \\ E-mail: cami@daad-alumni.de
}

\section{Doi:10.5901/ajis.2013.v2n2p515}

\begin{abstract}
In his well-known anticlerical views, part of the larger context of the Enlightenment's anticlericalism, Voltaire seems to represent an interesting case, as he utilizes phenomena and features of other religions to exert implicit criticism to Christianity. His tragedy Le fanatisme ou Mahomet le prophète, although focused in the character of the Prophet Muhammad, rather than criticizing the latter, seems to imply sharp criticism to religion in general and especially to Christianity and the Church. On the contrary, Voltaire even appraises the Prophet Muhammad in many cases for the way he established a new religion and fought against the old order. But even in such praise, he manifests an orientalist approach based on what N. Daniel called "doctrine about doctrine" and seems to support all the already traditional views on Islam and the Islamic society, established in the West since the middle ages.
\end{abstract}

Keywords: middle ages, Enlightenment, Religion, Islam, Christianity, Anticlericalism.

\section{Introduction: Voltaire and Mohammad}

"Ce fut certainement un très-grand homme [...] Conquérant, Législateur, monarque et pontife, il joua le plus grand rôle qu'on puisse jouer sur la terre aux yeux du commun des hommes." (Cit. in Mommsen, 18) ${ }^{1}$ These compliments Voltaire made for the Prophet Mohammad in 1756 in his Essai sur l'histoire générale et sur les mœurs et l'esprit des nations may seem acceptable and even charming to Muslim readers compared to the aggressive expressions of the medieval canon, but they are simply part of the ambiguity of Enlightenment about Islam, implying Muhammad's deliberate invention of a false religion and his violently imposing it on the world based on earthly rather than spiritual aims, and thus they can not but fit to the substance of the canon.

Focusing especially on the tragedy Le fanatisme ou Mahomet le prophète, N. Daniel (p. 310) states that Voltaire's attitude at this time (1742) was different from the medieval Christian one only in two respects: "In his tragedy, Fanatisme, ou Mahomet le prophète, he frankly preferred to invent his own legends, rather than use those already circulating, which were apparently not scurrilous enough for his purpose; and his arguments against Islam are not only, like the medieval ones, such as might be used against all revealed religion: they are intended so to be used."

\section{From a "False Prophet" to a "Useful Impostor"}

Such a use of arguments suitable for the attack against religion in general and not simply against Islam was part of the anticlericalism of the day, typical for the Enlightenment. In spite of all declarative efforts for religious tolerance, there was the tendency of displaying the Prophet Mohammad as an impostor no more to support - as in the middle Age - the idea of any supposed superiority of Christianity against Islam, but to illustrate through Islam the fraud and cheatings of all revealed religions. Although it is argued that the doctrine of the three imposters - Moses, Jesus and Mohammad - is to be attributed to the Emperor Frederick II of Hohenstaufen (d. 1250), writings of such content are to be evidenced only since the beginning of the early Enlightenment. (Mommsen, p. 14-15)

In this content, it is to be remarked that the men of the Enlightenment were able even to appraise Mohammad as a kind of more effective or charming imposter compared to Jesus and/or Moses. Thus, in Le dîner du Comte Boulainvilliers, Voltaire creates a situation of debate between Boulainvilliers and the Abot Couet, with the former stating the following in

${ }^{1}$ That was surely a very great man [...] Conqueror, Legislator, monarch and pontiff; he played the most important role one can play on the earth in the eyes of ordinary men. 
favor of Islam and Muhammad: "Du moins Mahomet a écrit et combattu; et Jésus n'a su ni écrire, ni se défendre. Mahomet avait le courage d'Alexandre avec l'esprit de Numa; et votre Jésus a sué sang et eau des qu'il a été condamné par ses juges. Le Mahométisme n'a jamais changé, et vous autres vous avez changé vingt fois toute votre religion." (Moland, v. 36, p. 378 ; Mommsen, p. 455). Voltaire's summarized picture of Muhammad, as he states in Lettre à M. De Cideville, Conseiller honoraire du parlement in Mai 5, 1740, was that of an ambiguously cruel and great man at the same time: "Mahomet le fanatique, le cruel, le fourbe, et, à la honte des hommes, le grand, qui de garçon marchand devient prophète, législateur et monarque." (Voltaire, 1792, p. 163)²

As in the medieval canon of doctrine about doctrine, that found the "hierarchic sense" shocked by Muhammad's rise to power from "almost complete insignificance", Voltaire also required from Muhammad, beside giving peaceful laws, being also born as a legitimate prince or at least properly elected by his people. But that a "merchant of camels" like him "should excite a revolt in his townlet; that, associated with some wretched Qurayshites, he should persuade them that he holds conversation with the angel Gabriel; that he should boast of being rapt to Heaven, and of having received there part of this unintelligible book which affronts common sense at every page; that he should put his own country to fire and the sword, to make this book respected; that he should cut the fathers' throats and ravish the daughters; that he should give the vanquished the choice between his religion and death; this certainly is what no man can excuse." (Cit. in Daniel, p. 311)

N. Daniel (ibid.) considers this quoted passage a "distillation of what was least acceptable in the mediaeval attitude, barely hidden under a polish of cultured enlightenment", a passage that "horrifies its modern reader by its disregard of the better information perfectly familiar to its author".

Coming back to Le fanatisme ou Mahomet le prophète, Voltaire describes his Mahomet as a fictional und historically inaccurate fanatic character, to whom accuracy is also devoid of interest. This character asks his successor to hide from people the "deceit" of his humanness, which would "destroy their faith", as the curtain is brought down with the following couplet (cit. in Daniel, p. 310):

Je dois régir en Dieu l'univers prévenu

Mon empire est détruit, si l'homme est reconnu. ${ }^{3}$

In religion, irrevocably committed to fanaticism, the gravamen of Voltaire's attack is hypocrisy (Cit. ibid.):

Dieu que j'ai fait servir au Malheur des humains

Adorable instrument de mes affreux desseins... ${ }^{4}$

In a lately "improved" or "softened" mood, with the will of being historically more accurate, Voltaire tried to get rid of, as he said, "what our historians, our rhetoricians and our prejudices tell us". In his Essai sur les mœurs, although maintaining his disapproval for the Prophet himself, he stressed that Muhammad's religion afterwards became more tolerant than he would have liked it to be, and to provide some evidence for this he contrasted what he considered the gentleness of Christ and the intolerance of Christians with this contrary state of things in Islam. He also conceded, inconsistently with his earlier positions, that Muhammad deceived himself in deceiving others. And in $\mathbf{1 7 7 2}$ he made even positive statements on Islam and the Prophet, such as:

Sa religion est sage, sévère, chaste et humaine : sage puisqu'elle ne tombe pas dans la démence de donner à Dieu des associés, et qu'elle n'a point de mystère; sévère puisqu'elle défend les jeux de hasard, le vin et les liqueurs fortes, et qu'elle ordonne la prière cinq fois par jour ; chaste, puisqu'elle réduit à quatre femmes ce nombre prodigieux d'épouses qui partageaient le lit de tous les princes de l'Orient ; humaine, puisqu'elle nous ordonne l'aumône, bien plus

\footnotetext{
2 Muhammad the fanatic, the cruel, the treacherous, and, for the shame of men, the great one, that from a young merchant becomes a prophet, a legislator and a monarch.

3 I must govern in God the warned universe. My Empire is destroyed if the man is recognized.

${ }^{4} \mathrm{God}$ that I've made to serve to the misfortune of humans / Adorable instrument of my awful designs... 
rigoureusement que le voyage de La Mecque. Ajoutez à tous ces caractères de vérité, la tolérance. (Moland, v. 28, p. $547)^{5}$

But Voltaire didn't change his mind on the issue of hypocrisy in Islam, stating that Muhammad was regarded as a great man even by those who knew he was an impostor, and was revered as a prophet by all the rest. (Daniel, p. 311-2)

\section{Le Fanatisme as an Anticlerical Work}

Although expressing in several occasions his disapproval for the content of this work of Voltaire, J. W. von Goethe, who translated it into German, justifies somehow the author by pointing out to that feature of the tragedy that while depicting Muhammad and Islam, in fact it intended to attack the Catholic Church, as well as fanaticism of religions in general, with the aim of ardently supporting the idea of a natural religion. And Goethe was not the only to perceive Voltaire's attitude in this way. Napoleon (cit. in Daniel, p. 312) also said: "Il (Voltaire) atteint Jésus-Christ dans Mahomet." As J. W. von Goethe met the Emperor in Erfurt and discussed with him about the translation of this work into German, made earlier by the young Goethe, Napoleon expressed his dislike about the tragedy (Prieur, p. 215):

\section{L'Empereur rétorqua :}

- Je n'aime pas cette pièce, c'est une caricature!

- Je suis de l'avis de Votre Majesté, j'ai fait ce travail à contre-cœur. Mais dans cette tragédie, dans ces tirades contre le fanatisme, ce n'est pas l'Islam qui était visé, mais l'Église catholique.

- Les allusions, dit Napoléon, sont tellement voilées que cet impertinent a pu dédier son œuvre au pape... qui lui a donné sa bénédiction.

And in fact, even though the play was since the beginning suspected of antiroyalism, Benedict XIV stated to have read it "con sommo piacere" and accepted politely and quite diplomatically Voltaire's obviously ironical dedication of the work to him. (Cf. Daniel, p. 310; Mommsen, p. 80)

\section{Conclusive Notes}

In conclusion, it may be remarked that Voltaire regarded Mohammad and Islam in the perspective of his clear anticlerical predisposition, which can be considered also a natural product of the Enlightenment period. In accordance with the medieval canon of "doctrine about doctrine", developed since the middle Ages by Christian polemists, Voltaire stressed the supposed cruelty and hypocrisy of Islam with the aim of using these charges to support the criticism of all revealed religion and especially Christianity and the Church. Although Voltaire's opinion changes somehow and becomes more moderate in a later age, its essence remains almost unchanged.

\section{References}

Mommsen, K. (2001), Goethe und der Islam, Frankfurt am Main: Insel Verlag.

Daniel, N. (1997), Islam and the West - The Making of an Image, Oxford: Oneworld

Moland, L. (Ed.) (1784-1789), Fuvres complètes de Voltaire, Kehl: Société Littéraire Typographique.

Voltaire (1792), Recueil des Lettres de Voltaire (1739-41), éd. Sanson et Compagnie.

Prieur, J. (2003), Muhammad, Prophète d'Orient et d'Occident, Paris: Éditions du Rocher.

\footnotetext{
${ }^{5}$ His religion is wise, severe, chaste and human: wise since it does not fall in the dementia of prescribing partners to God, and it has no mystery; severe since it prohibits gambling, wine and strong liquors and it orders prayer five times a day; chaste, since it reduces to four wives that prodigious number of women sharing the bed of all princes of the Orient; human, since it orders us alms, much more rigorously than the trip to Mecca. Add to all these characters of truth, the tolerance. 